\title{
PENERAPAN MODEL PEMBELAJARAN KOOPERATIF TIPE STAD DENGAN MEDIA ROTATION POINT UNTUK MENINGKATKAN HASIL BELAJAR
}

\author{
Ketut Suarni 1,*, Komang Ari Sulasih ${ }^{2}$ \\ 1 Jurusan Bimbingan Konseling. Universitas Pendidikan Ganesha, Indonesia \\ 2 Jurusan Pendidikan Guru Sekolah Dasar. Universitas Pendidikan Ganesha, Indonesia
}

\begin{abstract}
Abstrak
Penelitian ini bertujuan untuk meningkatkan hasil belajar Ilmu Pengetahuan Alam siswa kelas V semester II SD No 2 Penarukan dengan menggunakan model pembelajaran kooperatif tipe Student Teams Achievment Division (STAD) dan medai Rotation Point. Subjek penelitian ini adalah siswa kelas V, penelitian ini terdiri dari 2 siklus dimana masing-masing siklus terdiri dari perencanaan, pelaksanaan, observasi, dan refleksi. Proses pengumpulan data dalam penelitian ini menggunakan tes dan observasi. Data penelitian ini akan dianalisis kualitatif dan kuantitatif. Analisis kualitatif digunakan untuk menganalisis data yang menunujukkan dinamika proses dan untuk mendeskripsikan berbagai dinamikaperkembangan dan peningkatan yang terjadi. Berdasarkan hasil analisis, ditemukan pada siklus I didapatkan peningkatan hasil belajar siswa sebesar $54 \%$ dari semula pada tes awal sebesar $29 \%$ dan semakin meningkat pada siklus II sebesar $75 \%$. Hal ini dikarenakan menggunakan model pembelajaran kooperatif tipe Student Teams Achievment Division (STAD) dan media Rotation Point. Implikasi dari penelitian ini bahwa dalam upaya meningkatkan hasil belajar siswa, dan meningkatkan keaktifan siswa dalam mengikuti proses pembelajaran IPA.
\end{abstract}

Keywords:

Student Teams

Achievment Division,

rotation point, hasil

belajar IPA

\section{Pendahuluan}

Mata pelajaran Ilmu Pengetahuan Alam (IPA) merupakan salah satu cabang ilmu pengetahuan yang memegang peranan penting dalam perkembangan Ilmu Pengetahuan dan Tehnologi (IPTEK). Hasil dari perkembangan teknologi yang dinikmati dewasa ini merupakan salah satu aplikasi konsep dan prinsip IPA yang diwujudkan secara teknis dalam berbagai produk teknologi. Adapun tujuan dari pembelajaran IPA yaitu (1) agar siswa memahami konsep-konsep IPA dan keterkaitannya dengan kehidupan sehari-hari, (2) memiliki keterampilan proses untuk mengembangkan pengetahuan dan gagasan tentang alam sekitar, (3) mempunyai minat untuk mengenal dan mempelajari benda-benda serta kejadian di lingkungan sekitar, (4) memiliki sikap ingin tahu, tekun, terbuka, kritis, mawas diri, bertanggung jawab, bekerjasama dan mandiri mampu menerapkan berbagai konsep Ilmu Pengetahuan Alam, (5) mampu menggunakan teknologi sederhana mengenal, dan (6) memupuk rasa cinta terhadap alam sekitar, sehingga menyadari kebesaran dan keagungan Tuhan Yang Maha Esa.

Akan tetapi kenyataan di lapangan menunjukkan sebagian siswa belum mampu mengerti tentang mata pelajaran IPA dalam materi gaya dan sebagian lagi sudah mampu memahaminya. Hal ini dapat dilihat dari hasil obeservasi awal siswa pada hasil belajar IPA siswa masih rendah, yakni masih dibawah kategori tinggi yang telah ditetapkan di SD No. 2 Penarukan dan belum memenuhi standar KKM (Kriteria ketuntasan minimal) yang telah ditetapkan, yakni sebesar 67.

Dari hasil observasi awal yang dilakukan di SD No 2 Penarukan pada siswa kelas V dapat dilihat sebagian besar siswa belum mencapai standar KKM. Dari 24 jumlah siswa kelas V hanya 7 orang siswa yang mampu mencapai ketuntasan belajar dan 17 yang mencapai kategori rendah.Ini membuktikan bahwa hasil belajar yang ditunjukkan siswa pada mata pelajaran IPA masih rendah. Hasil belajar siswa kelas V SD No 2 Penarukan dapat di lihat pada tabel di bawah ini.

\footnotetext{
* Corresponding author.

E-mail Addresses niketut.suarni@undiksha.ac.id (Ketut Suarni), sulasih.ari@yahoo.com (Komang Ari Sulasih),
} 
Tabel. 1 Daftar Skor Data Awal Kelas V mata pelajaran IPA SD No 2 Penarukan

\begin{tabular}{clccc}
\hline No & \multicolumn{1}{c}{ Nama Siswa } & $\begin{array}{c}\text { Daftar Skor } \\
\text { Data Awal }\end{array}$ & KKM & Ket \\
\hline 1 & Kadek Somantara & 40 & 67 & BT \\
2 & Kadek Andre Suarjana & 50 & 67 & BT \\
3 & Kadek Indah Agustini & 55 & 67 & BT \\
4 & Gst Ayu Kade Sri & 45 & 67 & BT \\
5 & Made Agus Wahyu & 65 & 67 & BT \\
6 & Luh Putu Pebriani & 60 & 67 & BT \\
7 & Dina Tertiana & 70 & 67 & T \\
8 & Komang Bela Anggreni & 55 & 67 & BT \\
9 & Ketut Nita Adiningsih & 60 & 67 & BT \\
10 & Komang Ferdi Irawan & 65 & 67 & BT \\
11 & Kadek Widiariningsih & 40 & 67 & BT \\
12 & Luh Putu Septiani & 70 & 67 & T \\
13 & Kadek Fery Yudiawan & 55 & 67 & BT \\
14 & Gede Restu Ari & 45 & 67 & BT \\
15 & Komang Agnes Suantari & 50 & 67 & BT \\
16 & Komang Yunda Ardiani & 70 & 67 & T \\
17 & Komang Mas Taruna & 65 & 67 & BT \\
18 & Dewa Komang Budiantara & 50 & 67 & BT \\
19 & Dewa Putu Suartana & 70 & 67 & T \\
20 & Komang Bagus Putra D & 75 & 67 & T \\
21 & Gede Wardana & 75 & 67 & T \\
22 & Komang Mika Andayani & 70 & 67 & T \\
23 & Kadek Meta Yustiana & 65 & 67 & BT \\
24 & Elisa Kristinawati & 50 & 67 & BT \\
\hline & & Sumber : Arsip Nilai IPA Kelas V
\end{tabular}

Sebagian siswa di sekolah dasar cenderung menganggap mata pelajaran ini sulit untuk dimengerti.Hal ini tentu mempengaruhi minat siswa untuk belajar IPA yang berujung pada rendahnya hasil belajar siswa. Hal lain yang membuat kurangnya minta siswa untuk belajar IPA adalah guru dalam memberikan materi masih menggunakan metode ceramah saja, sehingga siswa sering merasa bosan belajar karena siswa tidak dapat berperan aktif dalam pembelajaran. Buku penunjang dan media pembelajaran yang sesuai dengan materi yang diberikan pun mempengaruhi minat siswa untuk belajar. Faktor tersebut sangat mempengaruhi hasil belajar siswa dalam mata pelajaran IPA.

Tipe STAD (Student Teams Achievement Divisions) yang merupakan salah satu model pembelajaran koopertif yang dikembangkan oleh Robert Slavin (dalam Nurhadi, dkk. 2004) membagi para siswa di dalam kelas menjadi beberapa kelompok atau tim, masing-masing terdiri atas 4 atau 5 anggota kelompokyang anggotanya heterogen, baik jenis kelamin,ras, etnik, maupun kemampuan (rendah, sedang, dan tinggi). Hal tersebut dapat mengkondisikan suasana lingkungan yang nyaman bagi siswa dalam proses pembelajaran. Hal ini dikarenakan siswa dapat saling bertukar pendapat dengan teman sebayanya, mendiskusikan masalah, dan siswa yang kurang mampu dalam menyelesaikan suatu masalah dapat belajar dari temannya yang lebih mampu dalam satu kelompok. Pembelajaran kooperatif tipe Students Teams Achievement Divisions (STAD) merupakan salah satu metode atau pendekatan dalam pembelajaran kooperatif yang paling sederhana, dan merupakan pendekatan yang paling baik untuk guru yang mulai menerapkan model pembelajaran kooperatif dalam kelas. Selain itu, STAD merupakan suatu metode pembelajaran yang efektif (Astawan, 2010).

STAD merupakan strategi alternatif untuk mencapai tujuan IPA antara lain meningkatkan kemampuan siswa untuk bekerja sama dengan orang lain, dan pada saat yang bersamaan dapat meningkatkan prestasi akademik siswa. Selain itu, pembelajaran kooperatif tipe STAD sesuai dengan pendidikan IPA karena memiliki pengaruh terhadap proses IPA, keterampilan IPA, sikap ilmiah, dan sikap demokratis. Pembelajaran kooperatif tipe STAD memberi kesempatan pada siswa untuk berdiskusi, berdebat, mengemukakan pendapat, dan mendengarkan pendapat orang lain. Motivasi dalam pembelajaran kooperatif tipe STAD adalah pemberian hadiah atau penghargaan untuk anak lebih giat lagi dalam belajar dam meningkatka prestasinya.

Media merupakan salah satu komponen penentu keberhasilan dalam pembelajaran. Dengan mengunakan media maka pembelajaran akan menyenangkan bagi siswa sehingga dapat meningkatkan 
hasil belajar siswa. Maka dari itu, guru perlu mengembangkan media yang inovatif dalam tiap pembelajaran.Media yang digunakan tidaklah harus dibeli, tapi dapat juga memanfaatkan barang-barang bekas yang ada disekitar.Media Rotation Point adalah salah satu media inovatif.Media ini terbuat dari gabus yang berbentuk lingkaran yang dapat diputar. Lingkaran tersebut berisikan point-point 10 sampai 50. Melalui penggunaan media ini dan dipadukan dengan model pembelajaran kooperatif tipe STAD diharapkan dapat meningkatkan motivasi siswa dalam belajar sehingga dapat meningkatkan hasil belajar siswa secara optimal.Berdasarkan uraian tersebut, penulis melakukan penelitian yang berjudul "Penerapan Model Pembelajaran Kooperatif Tipe Student-Teams Achievment Divisions (STAD) dengan Media Rotation Point untuk Meningkatkan Hasil Belajar Sains Siswa Kelas V Semester II SD No 2 Penarukan".

\section{Metode}

Objek penelitian ini adalah meningkatkan hasil belajar IPA dengan model pembelajaran kooperatif tipe Student Teams Achievement Division (STAD) dengan media Rotation Point. Penelitian dilakukan di SD No. 2 Penarukan. Yang dijadikan subjek dalam penelitian ini adalah siswa kelas V semester II yang berjumlah 24 orang terdiri dari 11 siswa laki-laki dan 13 siswa perempuan. Jenis penelitian ini adalah Penelitian Tindakan Kelas (PTK). Karwono (2008) menyatakan bahwa: "PTK adalah suatu bentuk kajian yang bersifat reflektif oleh pelaku tindakan, untuk meningkatkan kemantapan rasional dari tindakan-tinakan mereka dalam melaksanakan tugas, memperdalam pemahaman terhadap tindakan-tindakan yang dilakukan, serta memperbaiki dimana praktek-praktek pembelajaran dilaksanakan.

Jadi Penelitian Tindakan Kelas (PTK) adalah penelitian yang dilakukan oleh guru di dalam kelasnya sendiri melalui refleksi diri, dengan tujuan memperbaiki kinerja sebagai guru sehingga hasil belajar siswa menjadi meningkat. Guru sebagai peneliti merupakan faktor yang sangat berpengaruh untuk meningkatkan hasil belajar siswa dalam proses penelitian tindakan kelas. Dalam penelitian tindakan kelas, guru diharapkan ikut terlibat secara penuh dalam proses penelitian baik mulai dari tahap perencanaan, aksi, tindakan, dan refleksi. Guru mencari problem atau masalah, kemudian meneruskannya. Masalah yang diangkat hendaknya memang betul-betul terjadi di kelas tempatnya mengajar dan mencarikan solusi-solusi yang tepat seyogyanya mampu meningkatkan hasil belajar siswa di kelas itu sendiri.

Keterlibatan pihak luar hanya bersifat konsultatif dalam mencari dan mempertajam persoalanpersoalan pembelajaran yang dihadapi oleh guru yang sekiranya layak untuk dipecahkan melalui penelitian tindakan kelas. Jadi dalam penelitian tindakan kelas guru sebagai peneliti, dimana peran pihak luar sangat kecil pengaruhnya terhadap proses penelitian kelas tersebut.

Rancangan penelitian ini direncanakan selama 2 siklus tapi tidak menutup kemungkinan akan dilanjutkan ke siklus berikutnya apabila belum memenuhi target penelitian. Masing-masing siklus terdiri dari empat tahap yaitu: 1) perencanaan, 2) pelaksanaan, 3) observasi/evaluasi, dan 4) refleksi.

Data penelitian ini akan dianalisis dengan menggunakan analisis kualitatif dan kuantitatif. Analisis kualitatif digunakan untuk menganalisis data yang menunjukkan dinamika proses dengan memberikan pemaknaan secara kontekstual dan mendalam sesuai dengan permasalahan penelitian. Analisis kuantitatif digunakan untuk mendiskripsikan berbagai dinamika perkembangan dan peningkatan yang terjadi. Data yang dianalisis dengan cara deskriptif kualitatif adalah data yang didapat dari hasil observasi (lembar observasi terlampir), yaitu mengenai prilaku siswa, kesan siswa dalam PBM sebagai data pendukungnya dan dibuat simpulan.

\section{Hasil Dan Pembahasan}

Sebagaimana yang telah diuraikan sebelumnya, bahwa kemampuan siswa kelas V semester II SD No 2 Penarukan dalam pemahaman tentang mata pelajaran IPA masih kurang. Daya nalar dalam memahami materi tersebut sebagian besar siswa mengalami kesulitan.Untuk mendapat data akurat tentang kondisi awal sudah diuraikan pada subyek penelitian dengan memperhatikan nilai IPA berdasarkan observasi nilai data awal IPA kelas V semester II. Secara rinci dapat diuraikan bahwa dari 24 orang siswa kelas $\mathrm{V}$ yang hadir pada pelaksanaan tes awal, dengan menggunakan patokan ketuntasan belajar siswa yaitu 67 maka diperoleh hanya 7 orang yang tuntas dan 17 orang yang belum tuntas. Dengan nilai terendah 40, dan nilai tertinggi 75.

\section{Deskripsi Siklus I}


Pada siklus I, hasil tes akhir menunjukkan bahwa siswa yang belum tuntas berkurang yaitu dari 14 orang pada tes awal menjadi 11 orang yang tidak tuntas dalam keseluruhan. Walaupun sudah ada peningkatan, nilai yang diperoleh siswa sudah tergolong mampu untuk meningkatkan prestasi belajarnya.

Tabel 2. Data nilai hasil belajar IPA siswa pada Siklus I

\begin{tabular}{cccc}
\hline \multirow{2}{*}{ Nilai tes } & Frekuensi & $\begin{array}{c}\text { Jumlah } \\
\text { Nilai }\end{array}$ & $\begin{array}{c}\text { Keteranga } \\
\text { n }\end{array}$ \\
\hline 50 & 3 & 150 & BT \\
55 & 4 & 220 & BT \\
60 & 3 & 180 & BT \\
65 & 3 & 195 & BT \\
70 & 6 & 420 & $\mathrm{~T}$ \\
75 & 4 & 300 & $\mathrm{~T}$ \\
80 & 1 & 80 & $\mathrm{~T}$ \\
$\mathrm{~N}$ & 24 & 1490 & \\
\hline \multicolumn{5}{c}{ Rata-rata } & 62,08 \\
\hline Daya Serap & $62,08 \%$ \\
\hline
\end{tabular}

Sebagai akhir siklus I ini, semua data yang dikumpulkan akan dianalisis secara deskriptif dan memberikan penafsiran atas dasar dinamika perubahan proses yang terjadi, ini berarti data akhir siklus I belum dapat dianalisis secara statistik dinfrensial karena belum dapat diketahui dinamika perubahan secara hipotetis.

Berpedoman pada hasil analisis data seperti yang diuraikan di atas, selanjutnya diadakan refleksi. Pada tahap refleksi dilibatkan teman guru yang yang bertindak sebagai pengamat. Karena hasil masih tergolong sedang (ketuntasan belajar secara klasikal baru mencapai 54\% dan belum mencapai target. Walaupun sudah mengalami sedikit peningkatan dan hasilnya pun belum optimal, maka dari refleksi diputuskan untuk melakukan tindakan siklus II dengan mengadakan modifikasi beberapa langkah dari tindakan siklus I agar lebih efektif. Berdasarkan hasil diskusi dengan guru pengamat, berpedoman pada hasil refleksi maka tindakan siklus I yang dimodifikasi pada siklus II adalah sebagai berikut: a) Waktu pelaksanaan sebaiknya lebih ditepatkan lagi, dimana pada siklus I terjadi pergeseran waktu yang lumayan berpengaruh sehingga lepas dari rencana pelaksanaan. b) Siswa lebih diberikan kesempatan dan waktu yang lebih banyak dalam berdiskusi dimana pada siklus I waktu yang disediakan hanya 15 menit. dalam siklus II sebaiknya diberikan waktu yang lebih longgar lagi. Maka dari refleksi diputuskan untuk melakukan tindakan siklus II dengan mengubah/memodifikasi mengganti beberapa langkah pada siklus I yang dinilai kurang efektif.

\section{Deskripsi Siklus II}

Hasil tes akhir pada siklus II menunjukkan bahwa siswa yang belum tuntas dalam Kompetensi Dasar tersebut berkurang yaitu dari 7 orang pada siklus I menjadi semua siswa tuntas dalam pembelajaran.

Tabel 3. Data nilai hasil belajar IPA siswa pada Siklus II

\begin{tabular}{cccc}
\hline Nilai tes & Frekuensi & Jumlah nilai & Ket \\
\hline 70 & 8 & 560 & $\mathrm{~T}$ \\
75 & 11 & 825 & $\mathrm{~T}$ \\
80 & 2 & 160 & $\mathrm{~T}$ \\
85 & 3 & 255 & $\mathrm{~T}$ \\
$\mathrm{~N}$ & 24 & 1800 & \\
& $\sum \mathrm{X}$ & 1800 & \\
\hline \multicolumn{5}{c}{ Rata-rata } & 75,00 & \\
\hline \multicolumn{5}{c}{ Kaya Serap } & $75 \%$ & \\
\hline
\end{tabular}

Berpedoman pada hasil analisis data seperti yang diuraikan di atas, selanjutnya diadakan refleksi. Pada tahap refleksi dilibatkan teman guru yang yang bertindak sebagai pengamat. Karena hasil masih tergolong sedang (ketuntasan belajar secara klasikal mencapai 100\% dan sudah mencapai target. Sebagai 
akhir siklus II ini, semua data yang dikumpulkan akan dianalisis secara statistik infrensial memberikan penafsiran hipotetis tindakan yang diajukan dalam penelitian ini. Sehubungan dengan itu berikut ini akan disajikan hasil analisis dari masing-masing data yang terkumpul. Hasil analisis data hasil belajar siswa. Berdasarkan analisis data yang dilakukan pada akhir siklus II, menunjukkan bahwa ada peningkatan prestasi dibandingkan dengan hasil analisis siklus I, dapat dilihat melalui tabel berikut ini.

Tabel 4. Data hasil belajar siswa, daya serap, ketuntasan belajar siswa pada tes awal, tes akhir Siklus I dan Siklus II

\begin{tabular}{|c|c|c|c|c|c|c|c|}
\hline \multirow{3}{*}{$\begin{array}{l}\text { Nilai } \\
\text { Tes }\end{array}$} & \multicolumn{2}{|c|}{ Tes Awal } & \multicolumn{4}{|c|}{ Tes Akhir } & \multirow{3}{*}{$\begin{array}{c}\text { Keteran } \\
\text { gan }\end{array}$} \\
\hline & \multirow[t]{2}{*}{ Frekuensi } & \multirow{2}{*}{$\begin{array}{c}\text { Jml } \\
\text { Nilai }\end{array}$} & \multicolumn{2}{|c|}{ Siklus I } & \multicolumn{2}{|c|}{ Siklus II } & \\
\hline & & & Frekuensi & Jml Nilai & Frekuensi & Jml Nilai & \\
\hline 40 & 2 & 80 & - & - & - & - & BT \\
\hline 45 & 2 & 90 & - & - & - & - & BT \\
\hline 50 & 4 & 200 & 3 & 150 & - & - & BT \\
\hline 55 & 3 & 165 & 4 & 220 & - & - & BT \\
\hline 60 & 2 & 120 & 3 & 180 & - & - & BT \\
\hline 65 & 4 & 260 & 3 & 195 & - & - & BT \\
\hline 70 & 5 & 350 & 6 & 420 & 8 & 560 & $\mathrm{~T}$ \\
\hline 75 & 2 & 150 & 4 & 300 & 11 & 825 & $\mathrm{~T}$ \\
\hline 80 & - & - & 1 & 80 & 2 & 160 & $\mathrm{~T}$ \\
\hline 85 & - & - & - & - & 3 & 255 & $\mathrm{~T}$ \\
\hline \multirow[t]{2}{*}{$\mathrm{N}=$} & 24 & & 24 & & 24 & & \\
\hline & $\sum X$ & 1415 & & 1545 & & 1800 & \\
\hline \multicolumn{2}{|c|}{ Rata-rata Kelas } & 58,95 & & 62,08 & & 75,00 & \\
\hline \multicolumn{2}{|c|}{ Daya Serap (\%) } & $58,95 \%$ & & $62,08 \%$ & & $75 \%$ & \\
\hline \multicolumn{2}{|c|}{ Ketuntasan (\%) } & $29 \%$ & & $54 \%$ & & $100 \%$ & \\
\hline
\end{tabular}

Berdasarkan analisis data di atas diadakan refleksi. Oleh kerena itu, hasil yang diperoleh dari pelaksanan tindakan siklus II sudah menunjukkan peningkatan dibandingkan dengan sebelumnya baik dari segi proses maupun hasil, di samping itu semua kendala-kendala yang dihadapi pada siklus I sudah dapat diatasi dengan baik dan permasalahan yang dikemukakan pada awal penelitian sudah terjawab, maka pada saat refleksi akhirnya diputuskan penilitian ini diakhiri.

Pada pembahasan ini sejumlah temuan yang dianggap menonjol dari kedua siklus akan dibahas. Temuan-temuan yang dianggap menonjol antara lain:

Hasil penelitian tentang hasil belajar IPA siswa menunjukkan rata-rata hasil yang dicapai pada siklus II lebih besar dibandingkan hasil yang dicapai pada siklus I. Dalam aplikasi (penerapan) pendekatan struktural tipe Student Teams Achievement Division terlihat bahwa siswa dalam pembelajaran IPA lebih aktif, kreatif dan menggairahkan. Hal ini dapat dijelaskan bahwa dalam pembelajaran dengan menggunakan model pembelajaran STAD dan media Rotationt Point pembelajaran dirasa menyenangkan oleh siswa karena diakhir pelajaran diadakan kuis yang dapat meningkatkan minat belajar siswa dan mengingat materi yang diberikan guru. Dalam berdiskusi pada saat berkelompok pun siswa terlihat lebih aktif dan dapat bekerja sama dengan anggota kelompoknya.

Dari penjelasan di atas jelas terlihat bahwa aktivitas dalam pembelajaran dengan model pembelajaran kooperatif tipe STAD lebih aktif dan kreatif. Hal ini disebabkan karena tanggung jawab yang dibebankan pada masing-masing siswa yang mengharuskan mereka aktif, menemukan penyelesaian dari setiap permasalahan tersebut. Dengan meningkatnya aktivitas siswa dalam menemukan penyelesaian dari tiap permasalahan yang diberikan maka secara langsung akan bermuara pada peningkatan hasil belajar siswa tersebut. Selain itu ada kendala-kendala yang dihadapi selama penerapan model pembelajaran kooperatif tipe STAD namun semua kendala-kendala tersebut bisa diatasi dengan baik.

Sulit mengkondisikan siswa agar terbiasa dengan suasana pembelajaran yang diterapkan. Hal ini tampak jelas pada pertemuan pertama di mana siswa belum memahami benar cara kerja dan tugas mereka dalam proses pembelajaran, serta saat siswa mempresentasikan hasil kerja kelompoknya siswa tampak kurang bersemangat dengan orientasi kepada guru dan bukan seluruh siswa dan kendala ini sudah dapat diatasi dengan baik. 


\section{Simpulan Dan Saran}

Berdasarkan sajian hasil yang diperoleh dari pelaksanaan tindakan siklus I dan siklus II serta pembahasannya dapat ditarik simpulan adalah aplikasi model pembelajaran kooperatif tipe Student Teams Achievement Division (STAD) dengan dalam proses pembelajaran dapat meningkatkan hasil belajar. Peningkatan ini dinilai cukup signifikan mengingat siswa kelas V semester II yang menjadi subyek penelitian nilai rata-rata berkemampuan sedang dan rendah. Dengan demikian hipotesis yang berbunyi "Penerapan Model Pembelajaran Kooperatif tipe Student Teams Achievement Division dengan media Rotation Point dalam mata pelajaran IPA dapat meningkatkan hasil belajar siswa kelas V di Sekolah Dasar No. 2 Penarukan" ternyata terbukti.

Berdasarkan simpulan di atas, peneliti mengajukan saran sebagi berikut. Pertama Bagi calon guru agar dalam proses pembelajaran dapat menerapkan model pembelajaran kooperatif tipe Student Teams Achievement Divsion (STAD)dengan untuk dapat meningkat kan hasil belar siswa.keduaBagi calon guru hendaknya selalu mencari motivasi baru dalam pembelajaran sehingga suasana di kelas menjadi berkualitas, tidak membosankan bagi siswa.

\section{Daftar Pustaka}

Agung. (2010). "Penelitian Tindakan Kelas (Teori dan Analisis Data dalam PTK)”. Makalah disajikan dalam Workshop Jurusan Pendidikan Guru Sekolah Dasar FIP, Universitas Pendidikan Ganesha, Singaraja 27 September 2010.

Arsyad Azhar. (2002). Media Pembelajaran. Jakarta: PT RajaGrafindo Persada.

Fadil, Mohammad. (2009). "Pemanfaatan Media untuk Proses Pembelajaran yang Efektif dan Menyenangkan". Tersedia pada http://mfadil.blog.unej.ac.id/pemanfaatan-media-pembelajaran/ (diakses tanggal 10 Juni 2010)

Indra. (2009). "Faktor-Faktor Yang Mempengaruhi Hasil Belajar. Tersedia Pada Http://Indramunawar.Blogspot.Com/2009/06/Faktor-Faktor-Yang-Mempengaruhi-Hasil.Html (Diakses Tanggal 9 November 2010).

Jelantik, Ketut. (2009). "Pengertian Hasil Belajar". Tersedia pada http://pgri1amlapura.co.cc/?p=37 (diakses tanggal 6 Desember 2009).

Latip. (2009). "Pembelajaran IPA di Sekolah Dasar" Tersedia pada http://latip.blogspot.com/2009/05/pembelajaran-ipa-di-sekolah-dasar.html (diakses tanggal 9 Nopember 2010).

Mariana, Alit dan Wandy Praginda. (2009). Hakikat IPA dan Pendidikan IPA. Jakarta: Pusat Pengembangan dan Pemberdayaan Pendidik dan Tenaga Kependidikan Ilmu Pengetahuan Alam (PPPPTKIPA).

Nurkancana, Wayan dan Sunartana, PPN. (1990). Evaluasi Hasil Belajar. Surabaya: Usaha Nasional.

Prayekti. (2008). “Penerapan Model Pembelajaran Interaktif pada Mata Pelajaran IPA di SD”. Tersedia pada http://www.teknologipendidikan.net/wp content/uploads/2008/08/prayekti pengembangan model pembelajaran interaktif1.pdf. (diakses tanggal 12 Oktober 2010).

Rasana, I Dewa Putu Raka. (2010). “Model-model Pembelajaran Inovatif”. Makalah disajikan dalam Pelaksanaan P2M dengan judul Pelatihan Penerapan Model-model Pembelajaran Inovatif terhadap Guru-guru SD di Kabupaten Tabanan, Pendidikan Guru Sekolah Dasar, Fakultas Ilmu Pendidikan, universitas Pendidikan Ganesha, 2010.

Riyanto, Yatim. (2010). Paradigma Baru Pembelajaran: Sebagai Referensi bagi Guru/Pendidik dalam Implementasi Pembelajaran yang Efektif dan Berkualitas. Jakarta: Kencana Perdana Media Group.

Santyasa, I Wayan. (2007). “Landasan Konseptual Media Pembelajaran”. Makalah disajikan dalam Workshop Media Pembelajaran bagi Guru-Guru SMA Negeri Banjar AngkanKlungkung, Universitas Pendidikan Ganesha, Singaraja 10 Januari 2007

Saputra, Adi. (2010). "PTK, Membumikan Penelitian di Sekolah". Tersedia pada http://adisaputrabtm.wordpress.com/2010/10/24/ptk-membumikan-penelitian-di-sekolah/ (diakses tanggal 1 Nopember 2010). 
Subagiyo, Lambang, dkk. (2007). "Model Pembelajaran Kooperatif dalam Meningkatkan Motivasi, Partisipasi, dan Kualitas Hasil Belajar Siswa SMA Negeri 2 Samarinda".Didaktika, Volume 8, Nomor 1 (hlm. 38).

Sutriyono. (2007). Keefektifan Model Pembelajaran Kooperatif STAD (Student Teams Achievement Divisions) terhadap Pemahaman Konsep Materi PokokBangun Ruang Sisi Datar Siswa Kelas VIII SMP N 3 Dempet Tahun Pelajaran 2006/2007.Skripsi (tidak diterbitkan). Fakultas Matematika dan Ilmu Pengetahuan Alam Universitas Negeri Semarang

Tegeh, I Made. (2008). Media Pembelajaran. Singaraja: Program Pasca Sarjana Universitas Negeri Malang. 